\title{
ACCOUNTING QUALITY AND THE ADOPTION OF IASB STANDARDS - PORTUGUESE EVIDENCE
}

\section{ANA ISABEL MORAIS}

Professora Auxiliar do Departamento de Contabilidade do Instituto Superior de Ciências do Trabalho e da Empresa E-mail: aicm@iscte.pt

\section{JOSÉ DIAS CURTO}

Professor Auxiliar do Departamento de Métodos Quantitativos do Instituto Superior de Ciências do Trabalho e da Empresa

E-mail:dias.curto@iscte.pt

\section{ABSTRACT}

Through rule 1606/2002 by the European Commission, Portuguese listed firms were required to adopt IASB standards in the preparation and presentation of consolidated accounts for the periods beginning on or after 2005. IASB standards are developed in environments where accounting practices are especially directed at the private sector, reporting rules are largely unaffected by taxation requirements and capital is traditionally raised in public markets. However, in Portugal, financial reporting is closely related to tax reporting and banks play a key role in providing finance and inside access to information. We investigate whether adopting IASB standards is associated with higher earnings quality and higher value relevance. We compare the earnings quality and value relevance of accounting data of 34 Portuguese listed firms before (1995-2004) and after (2004-2005) the adoption of IASB standards. We find that firms, during the period when they adopt IASB standards, report less smooth earnings than those firms in periods when they adopted national accounting standards, which seems to suggest an improvement in earnings quality. However, we also find that the value relevance of accounting information decreases with the adoption of IASB standards.

Keywords: Earnings quality. International accounting standards. Value relevance. 


\section{INTRODUCTION}

Portuguese listed firms are required to adopt International Accounting Standards Board (IASB) standards in the preparation and presentation of consolidated accounts for periods beginning on or after 1 of January 2005 (Rule 1606/2002 of the European Commission). Until 2005, Portuguese listed firms were required to apply local standards (Plano Oficial de Contabilidade and Directrizes Contabilísticas).

IASB standards are developed in environments where accounting practices are especially directed at the private sector, reporting rules are largely unaffected by taxation requirements and capital is traditionally raised in public markets. IASB standards are clearly influenced by common-law countries, like the United States of America (USA) and the United Kingdom (UK). However, Portuguese institutional and legal environments are different and these differences affect the Portuguese accounting system.

Several studies show significant differences in ownership structures between code-law and common-law countries. Faccio and Lang (2002) find that firms from common-law countries are more likely to be widely held, while firms from code-law countries are family controlled. Faccio and Lang (2002) also find that, in countries like Portugal, the state controls a more significant proportion of firms, especially the largest, than in UK or USA. If we consider the state as a single entity, state-owned firms have a concentrated ownership. In these countries, agents of stakeholders tend to be informed by private and inside information and the need for timely public disclosure is less important. In a widely-dispersed share ownership, managers and shareholders' interests may diverge in important ways, raising the problem of asymmetric information. This problem is addressed through financial reporting and other forms of timely public disclosure.

The difference in ownership structures can be attributed to weak regulation in code-law countries and strong regulation in common-law countries. La Porta et al. (1997, 1998) show that common law systems, like UK or USA systems, have strong minority investor protection. On the contrary, civil law systems like the Portuguese have weak protection. They argue that the extent to which a country's laws protect investor rights and the extent to which those laws are enforced are the basic determinants of the ways in which corporate governance evolves in that country. Weak legal protections for minority shareholders can create opportunities for managerial abuses.

The design of accounting systems can also be affected by the orientation of a country's financial system. Financial systems can be classified as debt-based (such as Portugal) or market-based (such as UK or USA) (DEMIRGUEKUNT; LEVINE, 1999). In equity-based financial systems, the preference for equity ownership and the concern with the maximization of shareholder value tend to lead to a greater importance of accounting quality.

Finally, Portuguese financial reporting is closely related to tax reporting, which encourages income smoothing. On the contrary, IASB standards are separate from tax laws.
Previous studies on the quality of accounting standards provide mixed evidence. Barth et al. (2005) and Bartov et al. (2004) find that the adoption of IASB standards increases accounting quality. Based on a large sample of firms from different countries, Barth et al. (2005) find that, after IAS adoption, firms evidence less earnings management, more timely loss recognition and more value relevance of accounting data than firms that do not adopt. Bartov et al. (2004) also find that, for a sample of German firms, accounting earnings based on international accounting standards are more value relevant than those based on German accounting standards. However, Eccher and Healey (2003) find that accounting data based on international accounting standards are not more value relevant than those based on Chinese accounting standards. Hung and Subramanyam (2004) identify the sources of reconciling items between German accounting standards and international accounting standards and find that the adjustments to net income are not value relevant.

The objective of this study is to compare the accounting quality (earnings quality and value relevance) of Portuguese listed firms before and after the adoption of IASB standards.

First, we investigate if earnings quality increased with the adoption of IASB standards. Similar to Barth et al. (2005), we use five different measures of earnings quality: the variability of the change in net income scaled by total assets; the ratio of the variability of the change in net income to the variability of the change in operating cash flows; the Spearman correlation between accruals and cash flows; the coefficient of small positive income and the coefficient of large negative net income.

Second, we investigate the value relevance of accounting data. We regress the market price of shares on earnings and book value of equity in order to estimate $R^{2}$.

Our results seem to suggest that firms, during the period when they adopt IASB standards, report less smooth earnings than those firms in periods when they adopted national accounting standards, which seems to suggest an improvement in earnings quality. However, we also find that the value relevance of accounting information decreases with the adoption of IASB standards. This contradiction may be due to differences in our samples (we have fewer observations for IFRS/IAS adoption than for Portuguese accounting standards adoption) or because the period of IFRS/IAS adoption is a transition period (the quality of information may be lower than in future periods).

The structure of the paper is as follows. Section 2 defines accounting quality and identifies some measures of accounting quality used in previous studies. Section 2 also defines earnings quality and value relevance and revises previous studies. Section 3 provides a description of the sample, hypotheses and variables. Section 4 presents empirical results. Finally, Section 6 summarizes and concludes. 


\section{ACCOUNTING QUALITY}

The objective of financial reporting is to provide information about financial position, performance and changes in financial position of an entity that is useful in making economic decisions for a wide range of users, such as investors, employees, lenders, suppliers, customers, government and the public in general.

The quality of financial reporting has been receiving greater attention, especially after recent accounting scandals. Despite the increased attention, the term accounting quality is vague and difficult to define.

The objective of IASB is to develop, in the public interest, a single set of high quality accounting standards that require transparent and comparable information in financial statements. However, IASB does not present a definition of high quality.

Penman (2002) considers that accounting quality should be discussed in terms of shareholders' interests and the fair valuation of those interests. Penman's notion of accounting quality is based on the usefulness of information for the shareholders and the use of the modified shareholder perspective. Under this perspective, accounting should promote shareholders' interest but also consider the public interest.

Despite the inexistence of a clear definition of accounting quality, several studies use measures that are considered proxies of accounting quality, for example, earnings management, timely loss recognition and value relevance (BARTH et al., 2005). In this paper, we use earnings quality and value relevance as proxies of accounting quality.

\subsection{Earnings quality}

Penman (2002) considers that earnings quality is an important feature of financial reporting since investors buy future earnings.

Despite the importance of earnings for stakeholders, the term earnings quality is also vague and has different interpretations. Some authors relate earnings quality to the accurate representation of underlying economic transactions and events. Another interpretation focuses on persistence of earnings, where earnings of higher quality are sustainable and persist into the future. A more general interpretation of the persistence idea is suggested by tying earnings quality with predictability, claiming that earnings of higher quality are a good indicator of future earnings. Finally, some authors use the term in the context of accounting conservatism.

Cohen (2003) defines earnings quality as the degree to which accounting figures more accurately represent the underlying economic fundamentals of the firm and the extent to which they map into operating cash flow realizations. Schipper and Vicent (2003) view earnings quality as the extent to which reported earnings faithfully represent Hicksian income (maximum amount that can be consumed consistent with the maintenance of wealth). Chan et al. (2004) consider earnings quality as the degree to which reported income reflects operating fundamentals. Yee (2006) considers that earnings quality has two guises, first as a fundamental attribute and second as a financial reporting attribute. Fundamental earnings are the accounting profitability measure that gauges a firm's ability to make future dividend payments. Reported earnings are the imperfect signal of the fundamental earnings a firm announces. Therefore, earnings quality refers to how quickly and precisely reported earnings reveal fundamental earnings.

Kirschenheiter and Melumad (2004) consider that high quality earnings are more informative and closer to the long run value of the firm. Revsine et al. (1999) consider that earnings are of higher quality when they are sustainable. Also, Penman and Zhang (2002) define high quality earnings as sustainable earnings, that is, earnings that are a good indicator of future earnings.

White et al. (2003) define earnings quality as the degree of conservatism in a firm's reported earnings. Penman and Zhang (2002) also link earnings quality with conservatism.

Previous studies about earnings quality have used different measures to approach earnings quality. For example, Schipper and Vicent (2003) classify the earnings quality constructs in four categories: persistence, variability and predictability (SLOAN, 1996; SCHIPPER; VINCENT, 2003; RICHARDSON et al., 2005); relations among cash, accruals and income (JONES, 1991; DECHOW et al., 1995; DeANGELO, 1986; DECHOW; DICHEV, 2002); qualitative concepts in the FASB's conceptual framework and implementation decisions (incentives and expertise of preparers and auditors) (KIRSCHENHEITER; MELUMAD, 2004).

Similar to Barth et al. (2005), we use several measures of earnings management.

First, we use the variability of the change in net income scaled by total assets (LEUZ et al., 2003; BARTH et al., 2005).

$$
\triangle I N I T A=\frac{N I t}{T A t}-\frac{N I t-1}{T A t-1}
$$

Where: NI is net income and year-end TA total assets. $A$ higher variance is associated with a lower level of earnings smoothing.

Second, we use the ratio of the variability of the change in net income to the variability of the change in operating cash flows.

$$
\frac{\Delta N I}{\Delta O C F}=\frac{N I t-N I t-1}{O C F-O C F-1}
$$

Where: $\mathrm{NI}$ is net income and OCF cash flows from operations. If firms use accruals to manage earnings, the variability of the change in net income should be lower than that of operating cash flows.

Third, we use the Spearman correlation between accruals (hereafter $A C C$ ) and cash flows from operations. We expect that accruals and cash flows from operations are negatively correlated. 
Fourth, we test if firms manage earnings towards small positive earnings (BURGSTAHLER; DICHEV, 1997; LEUZ et al.,
2003; BARTH et al., 2005). The measure is the coefficient on small positive net income (SPOS) in the following regression:

$$
\begin{aligned}
& \operatorname{POST}(1,0)=\alpha_{0}+\alpha_{1} \operatorname{SIZE}_{i t}+\alpha_{2} G R O W T H_{i t}+\alpha_{3} E_{S S S U E_{i t}}+\alpha_{4} L E V_{i t}+ \\
& \alpha_{5} D I S S U E_{i t}+\alpha_{6} T R N_{i t}+\alpha_{7} O C F_{i t}+\alpha_{8} P O S T_{i t}+\varepsilon_{i t}
\end{aligned}
$$

Where: POST assumes the value 1 if the firm adopt IASB standards and 0 otherwise; SIZE is the natural logarithm of the market value at the year end; GROWTH is percentage change in sales; EISSUE is percentage change in common stock; LEV is total liabilities at the year end divided by the book value of equity at the year end; DISSUE is percentage change in total liabilities; TURN is sales scaled by total assets at the year end; OCF is cash flows from operations and SPOS is an indicator variable that equals 1 if net income scaled by total assets is between 0 and 0,01 .

Finally, we test timely loss recognition. Following Lang et al. (2003, 2005) and Barth et al. (2005), we measure timely loss recognition as the coefficient on the percentage of large negative net income (LNEG) in the following regression:

$$
\begin{aligned}
& \operatorname{POST}(1,0)=\alpha_{0}+\alpha_{1} \operatorname{SIZE}_{i t}+\alpha_{2} \text { GROWTH }_{i t}+\alpha_{3} \operatorname{EISSUE}_{i t}+\alpha_{4} L E V_{i t}+ \\
& \alpha_{5} \operatorname{DISSUE} E_{i t}+\alpha_{6} \operatorname{TURN}_{i t}+\alpha_{7} \mathrm{CF}_{i t}+\alpha_{8} L N E G_{i t}+\varepsilon_{i t}
\end{aligned}
$$

Where: POST equals 1 if the firm adopts IASB standards and 0 otherwise; SIZE is the natural logarithm of the market value at year end; GROWTH is percentage change in sales; EISSUE is percentage change in common stock; LEV is total liabilities at year end divided by the book value of equity at year end; DISSUE is percentage change in total liabilities; TURN is sales scaled by total assets at year end; OCF is cash flows from operations and LNEG is an indicator variable that equals 1 if net income scaled by total assets is less than -0.20 .

\subsection{Value relevance}

Ball and Brown (1968) were the first to report that stock prices react to the information disclosed in financial statements. Amir et al. (1993) were the first to use the term value relevance with the meaning of how well accounting data reflect information used by equity investors. Since then, several studies have investigated the price-earnings relation by using different variables.

Following Lang et al. (2003, 2005), we regress the market price of shares, as of six months after year end (hereafter PRICE), on book value of equity per share (hereafter BVEPS) and net income per share (hereafter NIPS) in order to estimate $R^{2}$ for the period that firms adopt international accounting standards and for the period that firms adopted Portuguese accounting standards:

$$
P_{R I C E_{i t}}=\alpha_{0}+\alpha_{1} \text { BVEPS }_{i t}+\alpha_{2} \operatorname{NIPS}_{i t}+\varepsilon_{i t}
$$

As the cross-sectional correlation in our sample is not very strong, we decided not to consider Barth's portfolio methodology (BARTH et al., 2005, 2008).

\section{RESEARCH DESIGN}

In this section, we describe the sample selection and research design.

\subsection{Sample}

Our sample consists of 34 Portuguese listed firms that prepared and presented consolidated accounts under IASB's standards in 2005. We consider the period between 1995 and 2004 (Portuguese GAAP adoption) and 20042005 (IFRS/IAS adoption). Since our sample includes only one country and due to small sample size, we did not use a matching sample procedure like Barth et al. (2005).

\subsection{Hypothesis}

The objective of this study is to compare the accounting quality (earnings quality and value relevance) of Portuguese listed firms before and after the adoption of IASB standards.
First, we investigate if earnings quality increased with the adoption of IASB standards. Therefore, our first prediction is related with earnings smoothing. Since Portugal is a code-law country, we expect that earnings smoothing is more pronounced when firms adopt national standards than when firms adopt IASB standards. Leuz et al. (2003) find that earnings smoothing is more pronounced in noncommon law countries. This leads to our first hypothesis:

$\mathrm{H} 1$ : We expect that earnings smoothing is more pronounced before IASB standard adoption than after IASB standard adoption.

Our second prediction is related to the value relevance of accounting data under national and international accounting standards. Alford et al. (1993) find that the association between earnings and stock returns is stronger in countries where capital is traditionally raised in capital markets and there are weaker links between financial and 
tax reporting. Additionally, Bartov et al. (2004) find that IAS based earnings are more value relevant than earnings produce under German GAAP, based on a sample of German firms traded on German stock exchanges. This leads to our second hypothesis:
H2: We expect that earnings produced under IASB standards are more value relevant than earnings produced under national accounting standards.

\section{RESULTS}

\subsection{Descriptive statistics}

Descriptive statistics are summarized in Table $1 \boldsymbol{\nabla}$.

Table 1 shows that, on the average, during the period of IASB standard adoption, firms have higher amounts of earnings per share, but smaller amounts of earnings scaled by total assets and higher amounts of change of earnings scaled by change of cash flows from operations. This seems to suggest that earnings based on IFRS/IAS have a greater variability than earnings based on Portuguese accounting standards. The table also indicates that, on the average, the book value of equity per share is higher during the period that firms adopted Portuguese accounting standards than during 2004-2005.

\subsection{Comparison of PGAAP period and IFRS/IAS period}

Our first prediction relates to earnings quality. We predict that earnings smoothing is more pronounced before than after IASB standard adoption.
In order to check our first hypothesis, we first compare the variability of net income before and after IFRS/IAS adoption, using the F-test (Table $2 \bullet$ ).

The results show that firms that adopt IFRS exhibit significantly higher variability in the change in net income, 0.035 versus 0.002 . This result seems to suggest that firms, during the period when they adopt IASB standards, report less smooth earnings than those firms in periods when they adopted national accounting standards. However, the variability can be determined by the variability of cash flow from operations. In order to test if the variability of net income is driven by the variability of cash flows from operations, we compare the ratio of the variability of the change in net income to the variability of the change in operating cash flows (Table $3 \bullet$ ).

Table 3 shows that the variance of change in net income to the variance in the change of cash flows from operations is higher in the period of IFRS/IAS adoption than in

Table 1 Descriptive statistics of variables

\begin{tabular}{l|c|c|c|c|c|c|c|c}
\multirow{2}{*}{ Variables } & \multicolumn{2}{|c|}{ IFRS } & \multicolumn{2}{c|}{ Firms } & \multicolumn{2}{c}{ PGAAP } & \multicolumn{2}{c}{ Firms } \\
\cline { 2 - 10 } & N Valid & Mean & Median & Std. Dev. & N Valid & Mean & Median & Std. Dev. \\
\hline$\Delta$ NITA & 35 & -0.013 & 0.002 & 0.186 & 264 & -0.001 & 0.000 & 0.050 \\
\hline ACC/TA & 68 & 4.144 & -0.023 & 20.613 & 232 & -0.687 & 0.054 & 14.210 \\
\hline OCF/TA & 68 & -0.047 & -0.045 & 0.092 & 271 & -0.040 & -0.030 & 0.080 \\
\hline SPOS & 69 & 0.093 & 0.080 & 0.161 & 271 & 0.050 & 0.050 & 0.070 \\
\hline LNEG & 69 & 0.014 & 0.000 & 0.120 & 303 & 0.013 & 0.000 & 0.000 \\
\hline LEV & 69 & 5.652 & 2.897 & 6.728 & 300 & 2.491 & 1.435 & 3.563 \\
\hline GROWTH & 35 & 0.202 & 0.050 & 0.522 & 267 & 0.218 & 0.084 & 1.139 \\
\hline EISSUE & 35 & 0.350 & 0.000 & 1.180 & 264 & 0.485 & 0.000 & 5.619 \\
\hline DISSUE & 35 & 0.180 & 0.020 & 0.690 & 262 & 2.359 & 0.069 & 18.711 \\
\hline TURN & 69 & 0.742 & 0.628 & 0.718 & 300 & 0.682 & 0.649 & 0.478 \\
\hline SIZE & 69 & 12.818 & 13.069 & 2.089 & 288 & 12.489 & 12.490 & 2.108 \\
\hline BVEPS & 69 & 2.460 & 1.633 & 2.994 & 296 & 3.936 & 1.594 & 11.849 \\
\hline NIPS & 69 & 0.484 & 0.212 & 1.877 & 297 & -0.044 & 0.138 & 3.411
\end{tabular}

IFRS firms include Portuguese listed firms that adopt IASB standards. PGAAP include Portuguese listed firms that adopt Portuguese generally accepted accounting principles. $\triangle$ NITA is change in net income scaled by total assets; $\triangle N \mathrm{NI} \triangle \mathrm{OCF}$ is net income divided by cash flows from operations; ACC/TA is accruals scaled by total assets; ACC is the difference between net income and cash flow from operations; OCF/TA is cash flow from operation scaled by total assets at the year end; SPOS is an indicator variable that equals 1 if net income scaled by total assets ranges between 0 and 0.01 ; LNEG is an indicator variable that equals 1 if net income scaled by total assets is less than -0.20; LEV is total liabilities at year end divided by the book value of equity at year end; GROWTH is percentage change in sales; EISSUE is percentage change in common stock; DISSUE is percentage change in total liabilities; TURN is sales scaled by total assets at year end; SIZE is the natural logarithm of the market value at year end; BVEPS is the book value of equity per share and NIPS is net income per share. 
Table 2 Variability of net income (F-test)

\begin{tabular}{l|c|c} 
& IFRS firms & PGAAP firms \\
Mean & -0.013 & -0.000 \\
\hline Variability & 0.035 & 0.002 \\
\hline $\mathrm{N}$ & 35 & 264 \\
\hline $\mathrm{Gl}$ & 34 & 263 \\
\hline $\mathrm{F}$ & 13.993 & \\
\hline $\mathrm{P}(\mathrm{F}<=\mathrm{f})$ uni-caudal & 0.000 & \\
\hline $\mathrm{F}$ critical uni-caudal & 1.474 &
\end{tabular}

Table 3 Variability of net income and cash flows from operations

\begin{tabular}{|c|c|c|}
\hline Variability & IFRS firms & PGAAP firms \\
\hline
\end{tabular}

the period of Portuguese accounting standard adoption. This finding is consistent with the fact that the adoption of IASB standards leads to a less smooth net income, since the variability is not only due to the variability in cash flows from operations.

In order to analyze the correlation between accruals and cash flows from operations, we first test the variables' normality assumption (Table $4 \mathbf{0}$ ). As one can see, the normality assumption, based on the Kolmogorov-Smirnov test, is rejected in cases of accruals scaled by total assets for the period that firms adopt IFRS/IAS and for cash flows from operations scaled by total assets for the period that firms adopted Portuguese accounting standards.

As we want to check if the observed correlation is statistically significant, the variables should be normal. As this assumption is violated in some comparison groups, we compute the nonparametric Spearman correlation coefficient. The results are shown next (Table $5 \mathbf{0}$ ).

Table 6 shows that the correlation between accruals and cash flows from operations is -0.755 for the period that firms adopt IFRS/IAS and -0.779 for the period that firms adopt Portuguese accounting standards. These results show that firms report more smooth net income when they adopt Portuguese standards than when they adopt IASB's standards. Finally, we use Eviews 5.0 to estimate the Logit model in order to estimate the coefficients of SPOS and LNEG. The results are shown below (Tables $6 \bullet$ and $7 \bullet$ ).

The coefficient of SPOS is positive (0.441) and the coefficient of LNEG is negative $(-0.883)$. However, none of the two is statistically significant.

Our second prediction is related to the value relevance of accounting data under national and international ac-

Table 4 | Variable normality (One-sample Kolmogorov-Smirnov Test)

\begin{tabular}{l|c|c|c|c} 
& \multicolumn{2}{|c|}{ IFRS } & firms & \multicolumn{2}{c}{ PGAAP } & firms \\
& ACC/TA & OCF/TA & ACC/TA & OCF/TA \\
\hline $\mathrm{N}$ & 68 & 68 & 271 & 271 \\
\hline Normal parameters ${ }^{\mathrm{a}, \mathrm{b}}$ & & & & \\
\hline Mean & -0.047 & 0.093 & -0.038 & 0.051 \\
\hline Std. Deviation & 0.092 & 0.161 & 0.076 & 0.069 \\
\hline Most extreme differences & & & & \\
\hline Absolute & 0.120 & 0.269 & 0.107 & 0.057 \\
\hline Positive & 0.120 & 0.269 & 0.107 & 0.069 \\
\hline Negative & -0.116 & -0.185 & -0.087 & 0.057 \\
\hline Kolmogorov-Smirnov Z & 0.988 & 2.214 & 1.763 & 0.934 \\
\hline Asymp. Sig. (2-tailed) & 0.283 & 0.000 & 0.004 & 0.347
\end{tabular}

Table 5 || Spearman Correlation between accruals and cash flows from operations

\begin{tabular}{|c|c|c} 
& IFRS firms & PGAAP firms \\
\hline Spearman's rho & $-0.755^{* *}$ & $-0.779 * *$
\end{tabular}

** Correlation is significant at the 0.01 level (2-tailed) 
Table 6 Logit model for the dependent variable SPOS

\begin{tabular}{|c|c|c|c|c|}
\hline Variable & Coefficient & Std. Error & z-Statistic & Prob. \\
\hline SIZE & -0.027 & 0.088 & -0.307 & 0.759 \\
\hline GROWTH & 0.004 & 0.019 & 0.219 & 0.827 \\
\hline EISSUE & -0.024 & 0.019 & -1.290 & 0.197 \\
\hline LEV & 0.173 & 0.038 & 4.550 & 0.000 \\
\hline DISSUE & -0.003 & 0.010 & -0.350 & 0.726 \\
\hline TURN & 0.199 & 0.370 & 0.537 & 0.591 \\
\hline OCF/TA & 9.544 & 2.712 & 3.519 & 0.000 \\
\hline SPOS & 0.441 & 0.417 & 1.057 & 0.291 \\
\hline $\mathrm{C}$ & -2.392 & 1.143 & -2.093 & 0.036 \\
\hline Mean dependent var & 0.253 & \multicolumn{2}{|c|}{ S.D. dependent var } & 0.436 \\
\hline S.E. of regression & 0.404 & \multicolumn{2}{|c|}{ Akaike info criterion } & 1.033 \\
\hline Sum squared resid & 44.857 & \multicolumn{2}{|c|}{ Schwarz criterion } & 1.149 \\
\hline Log likelihood & -137.702 & \multicolumn{2}{|c|}{ Hannan-Quinn criter. } & 1.079 \\
\hline Restr. log likelihood & -160.792 & \multicolumn{2}{|c|}{ Avg. log likelihood } & -0.485 \\
\hline LR statistic (8 df) & 46.182 & \multicolumn{2}{|c|}{ McFadden R-squared } & 0.144 \\
\hline Probability (LR stat) & 0,000 & \multirow{2}{*}{\multicolumn{2}{|c|}{ Total obs }} & \\
\hline Obs with $\mathrm{Dep}=0$ & 212 & & & 284 \\
\hline Obs with $\mathrm{Dep}=1$ & 72 & & & \\
\hline
\end{tabular}

Table 7 Logit model for the dependent variable SPOS

\begin{tabular}{|c|c|c|c|c|}
\hline Variable & Coefficient & Std. Error & z-Statistic & Prob. \\
\hline OCF/TA & 9.916 & 2.705 & 3.666 & 0.000 \\
\hline DISSUE & -0.003 & 0.010 & -0.320 & 0.749 \\
\hline EISSUE & -0.024 & 0.019 & -1.280 & 0.201 \\
\hline GROWTH & 0.005 & 0.018 & 0.261 & 0.794 \\
\hline LEV & 0.171 & 0.038 & 4.493 & 0.000 \\
\hline LNEG & -0.883 & 1.673 & -0.528 & 0.598 \\
\hline SIZE & 0.004 & 0.082 & 0.051 & 0.960 \\
\hline TURN & 0.272 & 0.370 & 0.735 & 0.463 \\
\hline $\mathrm{C}$ & -2.514 & 1.132 & -2.221 & 0.026 \\
\hline Mean dependent var & 0.253 & \multicolumn{2}{|c|}{ S.D. dependent var } & 0.436 \\
\hline S.E. of regression & 0.405 & \multicolumn{2}{|c|}{ Akaike info criterion } & 1.036 \\
\hline Sum squared resid & 44.999 & \multicolumn{2}{|c|}{ Schwarz criterion } & 1.152 \\
\hline Log likelihood & -138.122 & \multicolumn{2}{|c|}{ Hannan-Quinn criter. } & 1.082 \\
\hline Restr. log likelihood & -160.792 & \multicolumn{2}{|c|}{ Avg. log likelihood } & -0.486 \\
\hline LR statistic (8 df) & 45.341 & \multicolumn{2}{|c|}{ McFadden R-squared } & 0.141 \\
\hline Probability (LR stat) & 0.000 & & & \\
\hline Obs with Dep $=0$ & 212 & \multicolumn{2}{|l|}{ Total obs } & 284 \\
\hline Obs with Dep $=1$ & 72 & & & \\
\hline
\end{tabular}

POST is a variable that equals 1 if the firm adopt IAS/IFRS and 0 if the firm adopts Portuguese accounting standards.

counting standards. We predict that earnings produced under IASB standards are more value relevant than earnings produced under national accounting standards. To test this hypothesis, we regress the market price of shares, as of six months after the year end book value of equity per share and net income per share, in order to estimate $\mathrm{R}^{2}$ for the period that firms adopt international accounting standards and for the period that firms adopted Portuguese accounting standards. The results are shown in Tables $8 \bullet$ and 90 .

As one can see, the $\mathrm{R}$ square value is smaller within the period that firms adopt IFRS/IAS (2004-2005). As the difference is so high, it should be statistically significant. However, we also performed the Vuong test to compare the $\mathrm{R}$ square value in both groups of companies. The significance associated with the test is 0.000 and the equality assumption is clearly rejected. These results suggest that value relevance decreases with the adoption of IASB standards. These results are contradictory with previous literature that shows that the adoption of IASB's standards improves value relevance. However, these results can be justified by the fact that most political and economic influences on financial reporting practices remain local (BALL, 2006) and different. Capital markets are not perfectly integrated and 
Least squares for the dependent variable PRICE (Firms that adopt Portuguese accounting standards)

\begin{tabular}{l|c|c|c|c} 
Variable & Coefficient & Std. Error & t-Statistic & Prob. \\
BVEPS & 0.870 & 0.048 & 18.141 & 0.000 \\
\hline NIPS & 2.014 & 0.496 & 4.058 & 0.000 \\
\hline C & 2.002 & 0.336 & 5.956 & 0.000 \\
\hline R-squared & 0.850 & Mean dependent var & 6.009 \\
\hline Adjusted R-squared & 0.849 & S.D. dependent var & 13.574 \\
\hline S.E. of regression & 5.281 & Akaike info criterion & 6.177 \\
\hline Sum squared resid & 7724.197 & Schwarz criterion & 6.216 \\
\hline Log likelihood & -861.728 & F-statistic & 783.262 \\
\hline Durbin-Watson stat & 1.658 & Prob (F-statistic) & 0.000
\end{tabular}

Table 9 Least squares for the dependent variable PRICE (Firms that adopt IFRS/IAS)

\begin{tabular}{l|c|c|c|c} 
Variable & Coefficient & Std. Error & t-Statistic & Prob. \\
BVEPS & 0.327 & 0.105 & 3.107 & 0.003 \\
\hline NIPS & 0.075 & 0.168 & 0.447 & 0.656 \\
\hline C & 3.124 & 0.394 & 7.926 & 0.000 \\
\hline R-squared & 0.134 & Mean dependent var & 3.956 \\
\hline Adjusted R-squared & 0.109 & S.D. dependent var & 2.709 \\
\hline S.E. of regression & 2.557 & Akaike info criterion & 4.756 \\
\hline Sum squared resid & 451.154 & Schwarz criterion & 4.851 \\
\hline Log likelihood & -168.229 & F-statistic & 5.353 \\
\hline Durbin-Watson stat & 1.674 & Prob (F-statistic) & 0.007
\end{tabular}

economic and political integration are not yet fully complete (BALL, 2006). Therefore, some factors (such as legal syste$\mathrm{ms}$, financial systems, role of the accounting profession, tax alignment and ownership concentration) that in the past justified differences between accounting systems remain different among European countries. As a result of the influence of a country's institutional setting on accounting information, the economic consequences of changing from local accounting standards to international accounting stan- dards may vary across countries. Daske et al. (2007) found that the economic consequences of IFRS adoption depend on the extent to which IFRS adoptions represent a serious commitment to transparency. Daske et al. (2008) also found that capital market effects around mandatory IFRS adoption occur only in countries with relatively strict enforcement regimes and where the institutional environment provides strong incentives for firms to be transparent.

\section{SUMMARY AND CONCLUSIONS}

Portuguese listed firms are required to adopt IASB standards in the preparation and presentation of consolidated accounts for periods beginning on or after 1 of January 2005 (Rule 1606/2002 of the European Commission). Until 2005, Portuguese listed firms were required to apply local standards (Plano Oficial de Contabilidade and Directrizes Contabilísticas).

We investigate whether adopting IASB standards is associated with higher earnings quality and higher value relevance. We compare the earnings quality and value relevance of accounting data of 34 Portuguese listed firms before (19952004) and after (2004-2005) the adoption of IASB standards.
We find that firms, during the period when they adopt IASB standards, report less smooth earnings than those firms in periods when they adopted national accounting standards, which seems to suggest an improvement in earnings quality. However, we also find that the value relevance of accounting information decreases with the adoption of IASB standards. This contradiction may be due to differences in our samples (we have 72 observations for IFRS/IAS adoption and 212 for Portuguese accounting standards adoption), or because the period of IFRS/IAS adoption is a transition period (the quality of information may be lower than in future periods). 


\section{References}

ALFORD, A. et al. The relative informativeness of accounting disclosure in different countries. Journal of Accounting Research, v. 31, p. 183223, 1993. Supplement.

AMIR, E.; HARRIS, T.; VENUTI, E. A comparison of the value-relevance of US versus non-US GAAP accounting measures using form $20 \mathrm{~F}$ reconciliations. Journal of Accounting Research, v. 31, p. 230-264, 1993. Supplement.

BALL, R.; BROWN, P. An empirical evaluation of accounting income numbers. Journal of Accounting Research, v. 6, n. 2, p. 159-178, 1968.

. International financial reporting standards (IFRS): pros and cons for investors. Accounting and Business Research, International Accounting Policy Forum, p. 5-27, 2006.

BARTH, M.; LANDSMAN, W.; LANG, M. International accounting standards and accounting quality. Working Paper, Stanford University, 2005. BARTH, M. et al. Market reaction to the adoption of IFRS in Europe. Working Paper, 2008.

BARTOV, E.; GOLDBER, S.; KIM, M. Comparative value relevance among German, US and International Accounting Standards: a German stock market perspective. Working Paper, New York University, 2004.

BURGSTAHLER, D.; DICHEV, I. Earnings management to avoid earnings decreases and losses. Journal of Accounting and Economics, v. 24, p. 99-126, 1997.

CHAN, K. et al. Earnings quality and stock returns. Working Paper, University of Illinois at Urbana-Champaign, 2004.

COHEN, D. Quality of financial reporting choice: determinants and economic consequences. Working Paper, New York University, 2003.

DASKE, H. et al. Adopting a label: heterogeneity in the economic consequences of IFRS adoptions. Working Paper, 2007.

Mandatory IFRS reporting around the world: early evidence on the economic consequences. Journal of Accounting Research, forthcoming, 2008 .

DeANGELO, L. Accounting numbers as market valuation substitutes: a study of management buyouts of public stockholders. The Accounting Review, v. 61, p. 400-420, 1986.

DECHOW, P.; DICHEV, D. The quality of accruals and earnings: the role of accrual estimation errors. The Accounting Review, v. 77, p. 35-39, 2002. .; SLOAN, R.; SWEENEY, A. Detecting earnings management. The Accounting Review, v. 70, p. 193-225, 1995.

DEMIRGUE-KUNT, A.; LEVINE, R. Bank-based and market-based financial systems: cross-country comparisons. Working Paper, 1999.

ECCHER, E.; HEALEY, P. The role of international accounting standards in transitional economies: a study of the people's republic of China. Working Paper, Massachusetts Institute of Technology, 2003.

FACCIO, M.; LANG, L. The ultimate ownership of western European corporations. Journal of Financial Economics, v. 65, p. 365-395, 2002.

HUNG, M.; SUBRAMANYAM, K. Financial statement effects of adopting international accounting standards: the case of Germany. Working Paper, University of Southern California, 2004.

JONES, J. Earnings management during import relief investigations. Journal of Accounting Research, v. 29, p. 193-228, 1991.

KIRSCHENHEITER, M.; MELUMAD, N. Earnings' quality and smoothing. Working Paper, Columbia Business School, 2004.

La PORTA, R. F. et al. Legal determinants of external finance. Journal of Finance, v. 52, p. 1131-1150, 1997.

Law and finance. Journal of Political Economy, v. 106, p. 1113-1150, 1998.

LANG, M.; RAEDY, J.; YETMAN, M. How representative are firms that are cross listed in the United States? an analysis of accounting quality. Journal of Accounting Research, v. 41, p. 363-386, 2003.

_. _ _ Wilson, W. Earnings management and cross listing: are reconciled earnings comparable to US earnings? Working Paper, University of North California, 2005.

LEUZ, C.; NANDA, D.; WYSOCKI, P. Earnings management and investor protection: an international comparison. Journal of Financial Economics, v. 69, p. 505-527, 2003.

PENMAN, S. The quality of financial statements: perspectives from the recent stock market bubble. Working Paper, Columbia University, 2002.

; ZHANG, X. Accounting conservatism, the quality of earnings and stock returns. The Accounting Review, v. 77, p. 237-264, 2002.

REVSINE, L.; COLLINS, D.; JOHNSON, B. Financial reporting and analysis. Prentice Hall, Upper Saddle River, New Jersey, 1999.

RICHARDSON, S. et al. Accrual reliability, earnings persistence and stock prices. Journal of Accounting and Economics, v. 39, p. 437-485, 2005.

SCHIPPER, K.; VICENT, L. Earnings quality. Accounting Horizons, p. 97-1100, 2003. Supplement.

SLOAN, R. Do stock prices fully reflect information in accruals and cash flows about future earnings? The Accounting Review, v. 71, n. 3, p. 289-315, 1996.

WHITE, G.; SONDHI, A.; FRIED, D. The analysis and use of financial statements. 3. ed., John and Wiley and Sons, 2003.

YEE, K. Earnings quality and the equity risk Premium: a benchmark model. Contemporary Accounting Research, v. 23, n. 3, Fall 2006.

\section{NOTA - Endereço dos autores}

Instituto Superior de Ciências do Trabalho e da Empresa

Departamento de Contabilidade

Av. Das Forças Armadas, 1649-026

Lisboa - Portugal
Instituto Superior de Ciências do Trabalho e da Empresa

Departamento de Métodos Quantitativos

Av. Das Forças Armadas, 1649-026

Lisboa - Portugal 